THE WINCHESTER 
This page intentionally left blank 


\title{
THE WINCHESTER
}

\section{THE GUN THAT BUILT AN AMERICAN DYNASTY}

\author{
BY \\ Laura Trevelyan
}

\author{
Yale \\ UNIVERSITY \\ PRESS
}

NEW HAVEN \& LONDON 
First published 2016 in the United States by Yale University Press and in the United Kingdom by I.B. Tauris \& Co. Ltd.

Copyright () 2016 by Laura Trevelyan.

All rights reserved.

This book may not be reproduced, in whole or in part, including illustrations, in any form (beyond that copying permitted by Sections 107 and 108 of the U.S. Copyright Law and except by reviewers for the public press), without written permission from the publishers.

Yale University Press books may be purchased in quantity for educational, business, or promotional use. For information, please e-mail sales.press@yale.edu (U.S. office) or sales@yaleup.co.uk (U.K. office).

Typeset by Data Standards Ltd, Frome, Somerset. Printed in the United States of America.

Library of Congress Control Number: 2016938152

ISBN 978-0-300-22338-5 (hardcover: alk. paper)

A catalogue record for this book is available from the British Library.

This paper meets the requirements of ANSI/NISO Z39.48-1992 (Permanence of Paper). 
This book is dedicated to Mary Foote Rounsavall - custodian of the Winchester flame and beloved New England matriarch. 
This page intentionally left blank 